\title{
PDE2 and PDE10, but not PDE5, inhibition affect basic auditory information processing in rats
}

Citation for published version (APA):

Reneerkens, O. A. H., Sambeth, A., Blokland, A., \& Prickaerts, J. (2013). PDE2 and PDE10, but not PDE5, inhibition affect basic auditory information processing in rats. Behavioural Brain Research, 250, 251-256. https://doi.org/10.1016/j.bbr.2013.05.014

Document status and date:

Published: 01/08/2013

DOI:

10.1016/j.bbr.2013.05.014

Document Version:

Publisher's PDF, also known as Version of record

Document license:

Taverne

Please check the document version of this publication:

- A submitted manuscript is the version of the article upon submission and before peer-review. There can be important differences between the submitted version and the official published version of record.

People interested in the research are advised to contact the author for the final version of the publication, or visit the DOI to the publisher's website.

- The final author version and the galley proof are versions of the publication after peer review.

- The final published version features the final layout of the paper including the volume, issue and page numbers.

Link to publication

\footnotetext{
General rights rights.

- You may freely distribute the URL identifying the publication in the public portal. please follow below link for the End User Agreement:

www.umlib.nl/taverne-license

Take down policy

If you believe that this document breaches copyright please contact us at:

repository@maastrichtuniversity.nl

providing details and we will investigate your claim.
}

Copyright and moral rights for the publications made accessible in the public portal are retained by the authors and/or other copyright owners and it is a condition of accessing publications that users recognise and abide by the legal requirements associated with these

- Users may download and print one copy of any publication from the public portal for the purpose of private study or research.

- You may not further distribute the material or use it for any profit-making activity or commercial gain

If the publication is distributed under the terms of Article $25 \mathrm{fa}$ of the Dutch Copyright Act, indicated by the "Taverne" license above, 
Research report

\title{
PDE2 and PDE10, but not PDE5, inhibition affect basic auditory information processing in rats
}

\author{
O.A.H. Reneerkens ${ }^{a, c}$, A. Sambeth ${ }^{b, c}$, A. Blokland ${ }^{b, c}$, J. Prickaerts ${ }^{a, c, *}$ \\ a Department of Psychiatry and Neuropsychology, School for Mental Health and Neurosciences, Maastricht University, The Netherlands \\ ${ }^{\mathrm{b}}$ Department of Neuropsychology and Psychopharmacology, Maastricht University, The Netherlands \\ c European Graduate School of Neuroscience (EURON), The Netherlands
}

\section{H I G H L I G H T S}

- The PDE2-I BAY 60-7550 affects auditory information processing in the vertex

- The PDE10-I PQ-10 affects auditory information processing in the hippocampus.

- The PDE5-I vardenafil does not affect auditory information processing.

\section{A R T I C L E I N F O}

\section{Article history:}

Received 25 February 2013

Received in revised form 6 May 2013

Accepted 7 May 2013

Available online 17 May 2013

\section{Keywords:}

Sensory gating

PDE2

PDE5

PDE10

Auditory information processing

Schizophrenia

\begin{abstract}
A B S T R A C T
Phosphodiesterase type 2 (PDE2), type 10 (PDE10), and type 5 (PDE5) have been considered as relevant targets for cognition enhancement. Although it is well established that PDE inhibitors (PDE-Is) improve memory functions in animals, the effects on auditory information processing are less clear. The aim of this study was to test the effects of PDE2 (BAY 60-7550), PDE5 (vardenafil) and PDE10 (PQ-10) inhibition on sensory gating in rats. Vehicle or $1 \mathrm{mg} / \mathrm{kg}$ of a specific PDE-I was given orally $30 \mathrm{~min}$ before testing. EEG was recorded from the hippocampus, striatum and vertex. Sensory gating was found for the N1 in the vertex and hippocampus, as revealed by diminished amplitudes to S2 compared to S1. Administration of PDE-Is did not affect sensory gating. However, PDE2 inhibition increased the P1 peak after presentation of $\mathrm{S} 1$ at the vertex and $\mathrm{PQ}-10$ increased the $\mathrm{N} 1$ peak in general compared to vehicle treatment at the hippocampus. PDE2 and PDE10 inhibition affect auditory information processing in general, whereas PDE5 inhibition has no effect. These findings suggest that the positive effects of PDE5 inhibition on cognition previously found in animals are possibly the results of an effect on higher cognitive functioning specifically, whereas the cognition enhancing effects of PDE2 and PDE10 inhibition might also be influenced by effects on earlier stages of information processing.
\end{abstract}

(c) 2013 Elsevier B.V. All rights reserved.

\section{Introduction}

Phosphodiesterases (PDEs) are enzymes that selectively hydrolyze the second messengers cyclic guanosine monophosphate (cGMP) and/or cyclic adenosine monophosphate (cAMP) by breaking their phosphodiester bond. It has been shown that compounds that inhibit these PDEs, so-called PDE inhibitors (PDE-Is), improve cognitive functioning in a wide variety of behavioral paradigms (for a review see $[1,2]$ ). More specifically, it has been demonstrated in various tasks that cGMP-specific PDE5-Is improve memory and learning in unimpaired rodents,

\footnotetext{
* Corresponding author at: P.O. Box 616, 6200 MD Maastricht, The Netherlands. Tel.: +31 43 3881168; fax: +31433884086.

E-mail addresses: o.reneerkens@maastrichtuniversity.nl (O.A.H. Reneerkens), jos.prickaerts@maastrichtuniversity.nl (J. Prickaerts).
}

but also in animals with pharmacologically-induced memory deficits or in mice models of Alzheimer's disease (AD) (e.g. [3-8]). Furthermore, the PDE5-I sildenafil improved executive functioning in cynomolgus macaques [9]. In contrast, PDE5 inhibition failed to improve performance on memory and executive functioning tasks in healthy humans so far [10-12], although an improvement was found in patients suffering from erectile dysfunction [13]. The effects of PDE2-Is and PDE10-Is, which elevate both cGMP and cAMP, on cognition have not been investigated very extensively yet. However, it has been shown that the PDE2-I BAY 60-7550 can improve learning and memory in unimpaired rodents as well as in animals impaired by age or pharmacological intervention (e.g. [14-17]). Additionally, PDE2 inhibition improved memory function in a mouse model of $\mathrm{AD}$ [18] and executive functioning in pharmacologically-impaired rats [19]. Finally, PDE10 inhibition improved executive functioning and attention in rhesus monkeys [20] and reversed memory deficits induced by pharmacological 
intervention in rats $[21,22]$, but the results in healthy rodents varied $[20,22,23]$. These results have led to an increased attention for PDEs as a promising target for cognition enhancement.

Localization studies demonstrated that mRNA expression of PDE2 [24-27], PDE5 [24,25,28] and PDE10 [24,29-31] could all be detected in the cortex and hippocampus of mammals with PDE2 mRNA expression being highest and PDE5 mRNA expression being lowest. In addition, in the striatum predominantly PDE10 and - to a lesser extent - PDE2 mRNA expression was demonstrated as well. Combining the behavioral data in the memory deficit models with these localization data support the notion that these PDE-Is might be a suitable tool to treat memory deficits $[1,2,32]$.

Interestingly, the PDE10-I TP-10 was able to reverse damphetamine, an indirect-acting monoaminergic agonist known to disrupt sensory gating in humans and animals, induced deficits in a sensory gating paradigm which assesses basic information processing [33]. A study by Grauer et al. [22] indicated that PDE10 inhibition has a positive effect on prepulse inhibition (PPI), which also addresses information processing, in rats and mice. This implies that the therapeutic use of a PDE-I and in particular a PDE10-I might not be limited to memory dysfunction, but also extend to early stages of (auditory) information processing.

In the present study we therefore specifically investigated the effects of PDE inhibition on information processing, in particular sensory gating in rats. Sensory gating is an adaptive mechanism that helps to prevent overstimulation of higher cortical areas with sensory information (for review see e.g. [34]). This mechanism can be assessed by using a paradigm in which two identical, auditory stimuli are presented with an inter stimulus interval (ISI) of $500 \mathrm{~ms}$ and an inter trial interval (ITI) of at least $6 \mathrm{~s}$. Normally, the response to the first auditory stimulus (S1) is significantly larger than the response to the second stimulus (S2) reflecting sensory gating. However, this mechanism can be disrupted by e.g. pharmalogical intervention with d-amphetamine $[33,35]$ or clinical disorders such as Alzheimer's disease or schizophrenia [36-38].

In human subjects, the P50 (also known as P1) component of the event-related potential (ERP) is regarded to be the main component in the sensory gating paradigm, although the $\mathrm{N} 100$ (N1) and P200 (P2) seem to be involved as well (e.g. [39-42]). There is still a debate about which ERP component in rats is possibly the functional equivalent of the P50 in humans. It has been suggested that the P13 (P1), N40 (N1) or even P60 (P2) might be the functional equivalent of the $\mathrm{P} 50$ in humans, while it has also been suggested that the entire P1-N1-P2 complex is the most suitable candidate (e.g. [43-47]).

We previously demonstrated that PDE5 inhibition with vardenafil does not affect sensory gating in rats at doses which are normally able to improve memory $[6,48]$. This led us to conclude that the positive effects of PDE5 inhibition on cognition are most likely mediated by higher cognitive processes and not by more early stages of (basic) information processing. Since it is difficult to assess the effects of a compound on information processing separately in cognitive tasks such as the object recognition tasks, it is of utmost importance to also test its effects in paradigms assessing information processing, such as sensory gating. Especially to gain further insight into the underlying mechanisms of the cognition enhancing properties of a compound, since improved processing of task relevant information could also account for positive effect on cognition without affecting higher cognitive processing per se. In the current study we investigated the effects of a PDE2-I (BAY 60-7550) and PDE10-I (PQ-10) at the dosage that was previously found to improve memory function as well (e.g. $[21,49])$. For the EEG measurements we included the vertex, hippocampus and striatum as electrode locations. These three locations were included because of their involvement in sensory gating (e.g. [34,50,51]). We expected that the cGMP-specific PDE5-I vardenafil would not affect sensory gating as demonstrated previously [48]. Contrarily, the dual substrate PDE-Is BAY 60-7550 and PQ-10 were expected to have an effect on sensory gating, since it was shown that PDE10 inhibition was able to reverse an amphetamine induced sensory gating impairment [33].

\section{Methods}

\subsection{Animals}

All experimental procedures were approved by the local ethical committee for animal experiments of Maastricht University and met governmental guidelines. Fourteen 3-month-old male Wistar rats (Harlan, The Netherlands) were used with average body weights of $386 \mathrm{~g}( \pm 11.66)$. The animals were housed individually in standard Makrolon cages on sawdust bedding in an air-conditioned room (about $20^{\circ} \mathrm{C}$ ). They were kept on a $12 / 12$-h reversed light/dark cycle (lights on from $19.00 \mathrm{~h}$ to $7.00 \mathrm{~h}$ ) and had free access to food and water. The rats were housed in the same room as where they were tested. A radio, which was playing softly, provided background noise in the room. All testing was done between $9.00 \mathrm{~h}$ and $18.00 \mathrm{~h}$ in a shielded Skinnerbox.

\subsection{Surgery and EEG recordings}

The animals received $0.1 \mathrm{ml} / \mathrm{kg}$ Temgesic (Schering-Plough B.V., Utrecht, The Netherlands) subcutaneously $30 \mathrm{~min}$ before surgery as analgesia. Forene isoflurane (Abbott B.V., Hoofddorp, The Netherlands) was used as a general inhalation anesthetic. After the animal was placed into the stereotactic apparatus and an incision was made to expose the skull, lidocaine was applied as additional local anesthesia. Next, bregma was identified and the electrodes were unilaterally placed in the striatum (AP 0.48, ML-3.0, DV-5.0), dorsal hippocampus (AP-2.8, ML-1.8, DV-2.6) and at the vertex (AP-3.5, ML-1.0, DV-1.0) [52]. The reference and ground electrodes were both placed on the cerebellum. The electrodes and the connector were fixed to the skull by using three screws and Paladur denture acrylic (Heraeus Kulzer, Hanau, Germany). The animals were given at least two weeks to recover from the surgery.

In the first week after recovery, the animals were handled daily and adapted to the procedure, i.e. they were connected to the EEG set-up and allowed to explore the Skinnerbox in which the recording would take place. In addition the rats were adapted to p.o. administration procedures by saline injections $(2 \mathrm{ml} / \mathrm{kg})$. Next, the control condition was tested, i.e. animals were treated with vehicle; this was tested twice and averaged for the statistical analysis. Subsequently three doses of the PDE5-I vardenafil were randomly tested $(0.3,1,3 \mathrm{mg} / \mathrm{kg}$, p.o.). The results of this experiment were recently published [48] including only the animals whose dataset was complete and electrode localization was validated for the vehicle treatment and all PDE5-I conditions. Additionally, we randomly tested the PDE2-I BAY 60-7550 and the PDE10-I PQ-10 (both $1 \mathrm{mg} / \mathrm{kg}$ p.o.). The sensory gating paradigm consisted of 70 pairs of auditory stimuli which were presented with stimulus duration of $10 \mathrm{~ms}$ inter-stimulus interval of $500 \mathrm{~ms}$ and inter-trial interval 6-10 s. The EEG signal was sampled at $1000 \mathrm{~Hz}$, filtered between $1 \mathrm{~Hz}$ and $133.5 \mathrm{~Hz}$ and stored on a personal computer. The stimuli were $2500 \mathrm{~Hz}$ clicks with a sound intensity of $80 \mathrm{~dB}$ and duration of $10 \mathrm{~ms}$. After the study was finished, the animals were killed by decapitation and the brains were taken out. The brains were stored in $4 \%$ formaldehyde at $4-6{ }^{\circ} \mathrm{C}$ until electrode localization took place, which was done as described previously [48]

\subsection{Treatment}

BAY 60-7550, vardenafil, and PQ-10 were first dissolved in $1.5 \mathrm{ml}$ ethanol with $2 \%$ Tween 80 . After extraction of ethanol via vaporization under $\mathrm{N}_{2}$ gas, the compounds were dissolved in $0.5 \%$ methylcellulose. It was chosen to test the previously found most effective dose ( $1 \mathrm{mg} / \mathrm{kg}$, p.o.) of each PDE-I in improving memory in an object recognition task. All compounds were administered by oral gavage $(2 \mathrm{ml} / \mathrm{kg}$ ) 30 min before testing. BAY 60-7550 and vardenafil were a gift from BAYER (Wuppertal, Germany); PQ-10 was kindly donated by Johnson \& Johnson (Beerse, Belgium) All animals were treated with each condition once, except for the control condition (vehicle), which was tested twice as part of the training.

\subsection{Statistical analysis}

Segments between $100 \mathrm{~ms}$ before until $500 \mathrm{~ms}$ after stimulus onset were made for each stimulus type (S1 and S2) separately, using the last $100 \mathrm{~ms}$ before onset as baseline. High pass $(1 \mathrm{~Hz})$ and low pass $(30 \mathrm{~Hz})$ filters were applied. The segments were visually checked and removed from the data set if a movement artifact occurred within $500 \mathrm{~ms}$ after stimulus presentation. Both the grand average (all animals) and the individual data (single animal) were used to determine the auditory evoked potential (AEP) components. In general, P1 was defined as the most positive value between $20 \mathrm{~ms}$ and $55 \mathrm{~ms}$ after stimulus onset, $\mathrm{N} 1$ as the most negative value between $35 \mathrm{~ms}$ and $75 \mathrm{~ms}$, P2 as the most positive value between $55 \mathrm{~ms}$ and $100 \mathrm{~ms}$.

General linear models (GLM) repeated measures were used to analyze the amplitudes of the components. First, the responses to the S1 and S2 were compared for the vehicle condition to see whether sensory gating occurred. Next, the responses 
Vertex

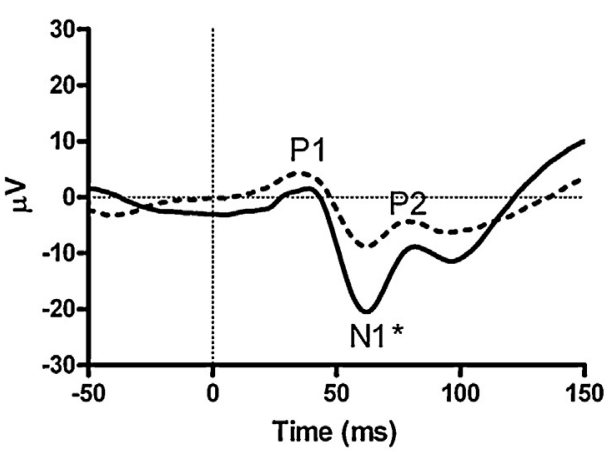

Hippocampus

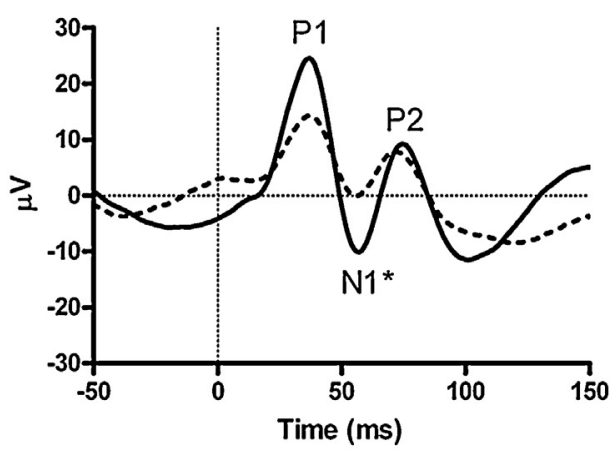

Striatum

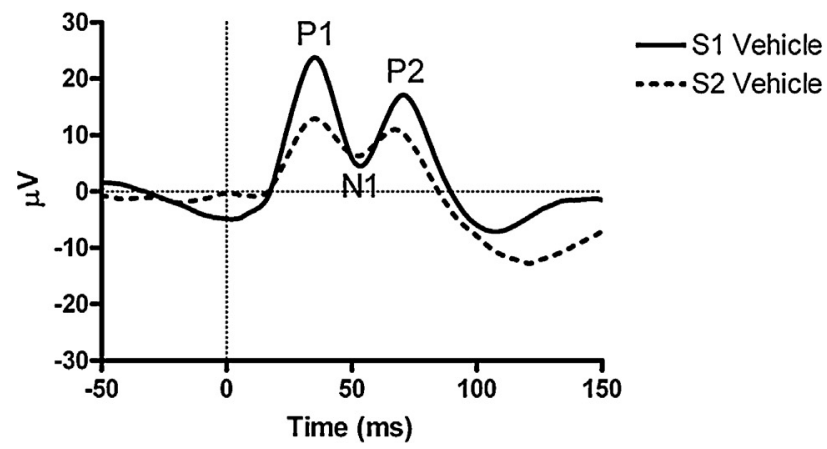

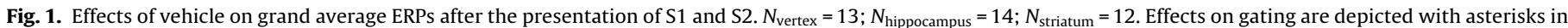
the saline condition $\left({ }^{*} P<0.05\right)$.

to the PDE-Is conditions were compared to placebo condition for each stimulus (treatment: vehicle and PDE-I) separately as well as for both stimuli together (treatment $\times$ stimulus). One animal was excluded from the vertex and two animals from the striatum electrodes because of no reliable EEG signal at the corresponding electrode.

\section{Results}

\subsection{Effects of vehicle on sensory gating}

The effects of vehicle treatment on sensory gating are depicted in Fig. 1. GLM repeated measures showed that the N1 peak was less negative after $S 2$ than $S 1$ in the vehicle condition $\left(F_{1,12}=6.12\right.$, $P<0.05)$ at the vertex and hippocampus $\left(F_{1,13}=6.20, P<0.05\right)$. In the striatum, no effects were found. Thus, sensory gating was generally found in the hippocampus and the vertex.

\subsection{Effects of PDE inhibition on information processing}

\subsubsection{Vertex}

The PDE2-I BAY 60-7550 did not have an effect on the ERP components of the S2 or sensory gating. However, GLM repeated measures showed that the P1 peak of the S1 was more positive after BAY 60-7550 than vehicle treatment $\left(F_{1,10}=7.59, P<0.05\right)$ (see Fig. 2). No other effects of PDE2 inhibition were found. In addition, treatment with the PDE5-I vardenafil or the PDE10-I PQ-10 did not affect S1, S2 or sensory gating (data not shown).

\subsubsection{Hippocampus}

No effects of PDE2 or PDE5 inhibition on the ERP components of the S1, S2 or sensory gating were found (data not shown). The PDE10-I PQ-10 did not affect S1 or S2 separately either. Yet, the GLM repeated measures with treatment as well as stimulus as a within subject variable showed that PQ-10 treatment increased the overall N1 compared to vehicle treatment $\left(F_{1,13}=4.71, P<0.05\right)$. This is also illustrated in Fig. 3 showing the effects of all PDE-Is on their hippocampal N1 peaks that showed sensory gating in the placebo condition (see Fig. 1).

\subsubsection{Striatum}

GLM repeated measures demonstrated no effects of PDE2 $(n=11)$, PDE5 $(n=11)$ or PDE10 $(n=12)$ inhibition on the ERP components of S1, S2 or sensory gating (data not shown).

\section{Discussion}

The present study showed that after treatment with vehicle the $\mathrm{N} 1$ in the vertex and hippocampus was less negative after S2 than after $\mathrm{S} 1$ indicating sensory gating in both electrode locations. However, in the striatum, no sensory gating was found. None of the PDE-Is affected sensory gating directly as no stimulus $\times$ treatment interaction was found. Yet, it was demonstrated that the PDE2-I BAY 60-7550 increased the P1 peak after S1 compared to vehicle in the vertex. In addition, the PDE10-I PQ-10 affected the N1 in general, with this peak being more negative after PQ-10 than vehicle treatment in the hippocampus.

Administration of the PDE5-I vardenafil did not have an effect on sensory gating as we already recently showed in rats and humans [48]. Although the effect of PDE5 inhibition on learning and memory has been widely investigated (for review see e.g. [2,3]), little is known about the effects on ERPs. A study by Schultheiss et al. [12] investigated the effects of PDE5 inhibition on ERPs in humans. They showed that sildenafil ( $100 \mathrm{mg}$ p.o., $1 \mathrm{~h}$ before testing) reduced N150/250 and increased P300 activity related to the improvement in attention in healthy human adults. Additionally, to our knowledge only one study has thus far examined the effects of PDE5 inhibition on ERPs and information processing in animals [48]. Our results indicate that the effects of PDE5 inhibition during memory tasks using the same dosage range $[6,8,53-56]$ are predominantly 

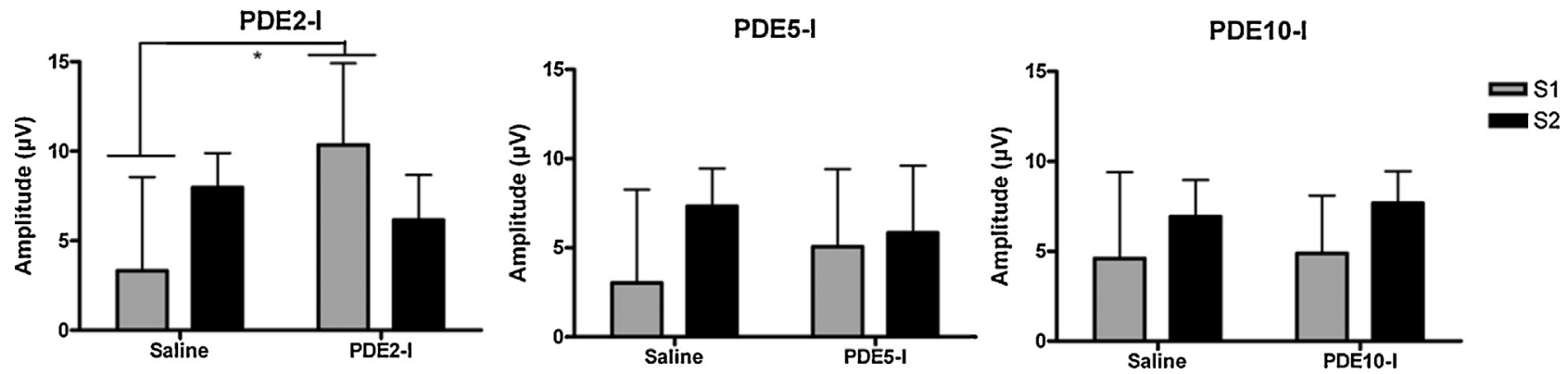

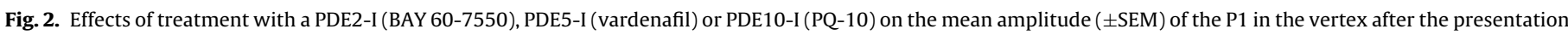
of S1 and S2. $N_{\mathrm{PDE} 2}=11 ; N_{\mathrm{PDE} 5}=11 ; N_{\mathrm{PDE} 10}=12$.

mediated by effects on higher cognitive processes and not on early stages of information processing, since the early ERP components were not affected by PDE5 inhibition.

The PDE2-I BAY 60-7550 and PDE10-I PQ-10 did not affect sensory gating either. Schmidt et al. [33] previously showed that the PDE10-I TP-10 (3 mg/kg) reversed sensory gating deficits in the hippocampus induced by d-amphetamine. However, this study was performed in anesthetized rats while we used freely moving animals in the present study. In addition, we did not use a deficit model here, which clearly could explain the difference between both studies. Furthermore, based on the $\mathrm{IC}_{50}$ values it could be argued that PQ-10 is about 10 times less potent than TP-10 [57], yet we tested PQ-10 at a dose $(1 \mathrm{mg} / \mathrm{kg})$ known to improve memory processes [21]. Finally, the routes of administration differed between both studies (intravenously versus orally), which might also have an effect. In contrast to auditory sensory gating, the TP10 compound did not have an effect on sensorimotor gating in PPI paradigms [33]. However, the PDE10-Is papaverine and MP10 , approximately 5 times less potent and 10 times more potent than PQ-10 respectively [57,58], reversed MK-801, an N-methylD-aspartate (NMDA) receptor antagonist that disrupts particularly memory and attention processes, induced PPI deficits in rats and improved PPI-linked sensorimotor gating in healthy mice [22]. This suggests that it would be interesting to test PQ-10 in a PPI paradigm as well. Nevertheless, although we presently did not find a direct effect of PDE10 inhibition with PQ-10 nor of PDE2 inhibition with BAY 60-7550 on auditory sensory gating, PQ-10 as well as BAY $60-7550$ showed effects on information processing. Administration of BAY 60-7550 increased the P1 peak after presentation of $\mathrm{S} 1$ at the vertex, which might indicate an arousal effect, and PQ-10 increased the $\mathrm{N} 1$ peak at the hippocampus in general compared to vehicle treatment, which might point to a general enhancing effect on auditory information processing.

Interestingly, the PDE-Is that have an effect on information processing both affect cGMP and cAMP, whereas PDE5 is cGMP specific (e.g. [59]). The fact that we only found an effect of the dual substrate PDE-Is suggests that information processing might be influenced by cAMP. This would also be in line with previous findings of Maxwell et al. [60] who demonstrated that the cAMP-specific phosphodiesterase type 4 inhibitor (PDE4-I) rolipram enhanced the amplitude of the P20 (P1) and N40 (N1) peaks after $\mathrm{S} 1$ in the hippocampus in non-anesthetized mice in a sensory gating paradigm. In addition, this compound reversed an amphetamine-induced deficit at these peaks after S1. However, no effects on sensory gating were found for the P20 and N40. Another study [35] showed that the PDE4-I Ro-20-1724 increased the response to S1 at the P20 (P1) and N40 (N1) peaks in the hippocampus in mice in a sensory gating paradigm as well. In addition, they found that this PDE4-I reversed a decreased N40 after S1 and a N40 gating deficit induced by d-amphetamine. Interestingly, they did not find an effect of PDE4 inhibition on a d-amphetamine induced PPI deficit in mice. These results imply that dual substrate as well as CAMP specific PDE-Is are able to affect auditory information processing in a sensory gating paradigm, but that the results differ when it comes to other paradigms such as PPI.

Furthermore, the fact that PDE5 inhibition did not affect basic auditory information processing, whereas PDE2 and PDE10 inhibition did have an effect, might also be explained by previous localization data of the corresponding PDEs. PDE2 mRNA expression has been localized in the striatum, hippocampus and cortex, whereas PDE10 is predominantly localized in the striatum and to a lesser extent in the hippocampus and cortex [24-26,29-31]. Given the high expression of PDE2 and PDE10 in the striatum, BAY 60-7550 and/or PQ-10 might be expected to affect information processing in general as in the hippocampus and the vertex. Yet the lack of an effect of PDE inhibition on information processing in the striatum suggests that these types of PDE in the striatum are not implicated in auditory information processing. PDE5 can be detected in the CNS as well, but at a lower level than PDE2 and PDE10 [24]. So it might also be the case that the amount of PDE5 in the CNS is just too low to affect information processing.
PDE2-1

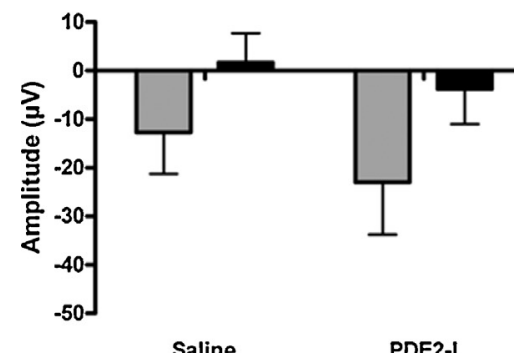

PDE5-I

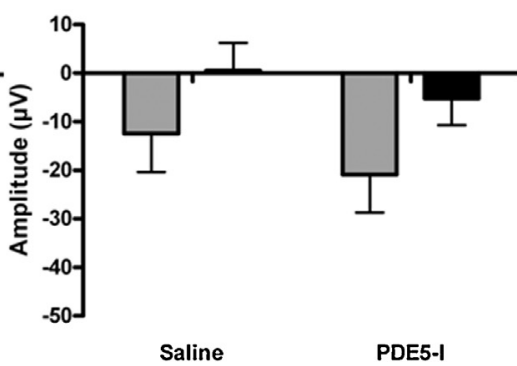

PDE10-I

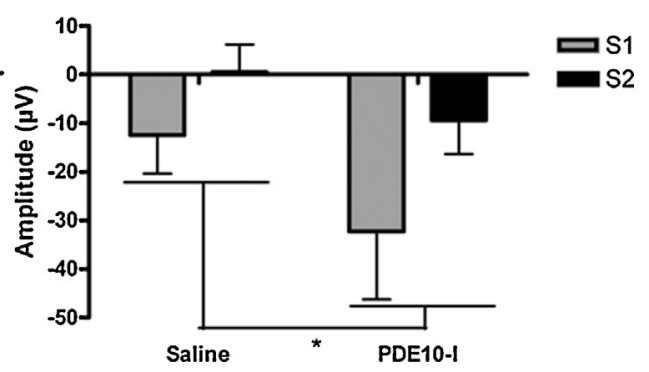

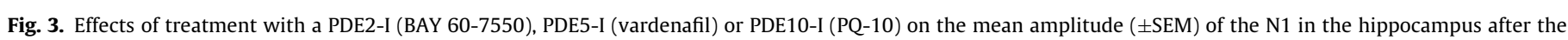
presentation of S1 and S2. $N_{\mathrm{PDE} 2}=13 ; N_{\mathrm{PDE} 5}=14 ; N_{\mathrm{PDE} 10}=14$. 
To summarize, the PDE5-I vardenafil did not have an effect on basic auditory information processing examined in a sensory gating paradigm. This in contrast to administration of the PDE2-I BAY 60-7550 or PDE10-I PQ-10 which affected auditory information processing in general. These results imply that the positive effects of PDE5 inhibition on cognition previously found in animals are possibly the results of an effect on higher cognitive functioning specifically whereas the cognition enhancing effects of PDE2 and PDE10 inhibition might also be influenced by effects on earlier cognitive processes such as information processing. To further elucidate the effects of PDE inhibition on information processing deficit models (e.g. d-amphetamine) and other paradigms (e.g. PPI) could be employed.

\section{Conflict of interest}

None declared.

\section{References}

[1] Blokland A, Menniti FS, Prickaerts J. PDE inhibition and cognition enhancement. Expert Opinion on Therapeutic Patents 2012:22:349-54.

[2] Reneerkens OA, Rutten K, Steinbusch HW, Blokland A, Prickaerts J. Selective phosphodiesterase inhibitors: a promising target for cognition enhancement. Psychopharmacology (Berl) 2009;202:419-43.

[3] Prickaerts J, Sik A, van Staveren WC, Koopmans G, Steinbusch HW, van der Staay FJ, et al. Phosphodiesterase type 5 inhibition improves early memory consolidation of object information. Neurochemistry International 2004;45:915-28.

[4] Puzzo D, Staniszewski A Deng SX, Privitera L, Leznik E, Liu S, et al. Phosphodiesterase 5 inhibition improves synaptic function, memory, and amyloid-beta load in an Alzheimer's disease mouse model. Journal of Neuroscience 2009;29:8075-86.

[5] Cuadrado-Tejedor M, Hervias I, Ricobaraza A, Puerta E, Perez-Roldan JM, GarciaBarroso C, et al. Sildenafil restores cognitive function without affecting betaamyloid burden in a mouse model of Alzheimer's disease. British Journal of Pharmacology 2011;164:2029-41.

[6] Reneerkens OA, Rutten K, Akkerman S, Blokland A, Shaffer CL, Menniti FS, et al. Phosphodiesterase type 5 (PDE5) inhibition improves object recognition memory: indications for central and peripheral mechanisms. Neurobiology of Learning and Memory 2012;97:370-9.

[7] Patil CS, Jain NK, Singh VP, Kulkarni SK. Differential effect of the PDE5 inhibitors, sildenafil and zaprinast, in aging - and lippolysaccharide-induced cognitive dysfunction in mice. Drug Development Research 2004;63:66-75.

[8] Devan BD, Bowker JL, Duffy KB, Bharati IS, Jimenez M, Sierra-Mercado Jr D, et al. Phosphodiesterase inhibition by sildenafil citrate attenuates a maze learning impairment in rats induced by nitric oxide synthase inhibition. Psychopharmacology (Berl) 2006;183:439-45.

[9] Rutten K, Basile JL, Prickaerts J, Blokland A, Vivian JA. Selective PDE inhibitors rolipram and sildenafil improve object retrieval performance in adult cynomolgus macaques. Psychopharmacology (Berl) 2008;196:643-8.

[10] Reneerkens O, Sambeth A, Ramaekers J, Steinbusch H, Blokland A, Prickaerts J. The effects of the phosphodiesterase type 5 inhibitor vardenafil on cognitive performance in healthy adults: a behavioralelectroencephalography study. Journal of Psychopharmacology 2013, http://dx.doi.org/10.1177/0269881113477747.

[11] Grass H, Klotz T, Fathian-Sabet B, Berghaus G, Engelmann U, Kaferstein $H$. Sildenafil (Viagra): is there an influence on psychological performance? International Urology and Nephrology 2001;32:409-12.

[12] Schultheiss D, Muller SV, Nager W, Stief CG, Schlote N, Jonas U, et al. Central effects of sildenafil (Viagra) on auditory selective attention and verbal recognition memory in humans: a study with event-related brain potentials. World Journal of Urology 2001;19:46-50.

[13] Shim YS, Pae CU, Kim SW, Kim HW, Kim JC, Koh JS. Effects of repeated dosing with Udenafil (Zydena) on cognition, somatization and erection in patients with erectile dysfunction: a pilot study. International Journal of Impotence Research 2011;23:109-14.

[14] Boess FG, Hendrix M, van der Staay FJ, Erb C, Schreiber R, van Staveren W, et al. Inhibition of phosphodiesterase 2 increases neuronal cGMP, synaptic plasticity and memory performance. Neuropharmacology 2004;47:1081-92.

[15] van Donkelaar EL, Rutten K, Blokland A, Akkerman S, Steinbusch HW, Prickaerts J. Phosphodiesterase 2 and 5 inhibition attenuates the object memory deficit induced by acute tryptophan depletion. European Journal of Pharmacology 2008;600:98-104

[16] Domek-Lopacinska K, Strosznajder JB. The effect of selective inhibition of cyclic GMP hydrolyzing phosphodiesterases 2 and 5 on learning and memory processes and nitric oxide synthase activity in brain during aging. Brain Research 2008;1216:68-77.

[17] Rutten K, Prickaerts J, Hendrix M, van der Staay FJ, Sik A, Blokland A. Timedependent involvement of cAMP and cGMP in consolidation of object memory: studies using selective phosphodiesterase type 2, 4 and 5 inhibitors. European Journal of Pharmacology 2007;558:107-12.

[18] Sierksma AS, Rutten K, Sydlik S, Rostamian S, Steinbusch HW, van den Hove DL, et al. Chronic phosphodiesterase type 2 inhibition improves memory in the APPswe/PS1dE9 mouse model of Alzheimer's disease. Neuropharmacology 2012;64:124-36

[19] Rodefer JS, Saland SK, Eckrich SJ. Selective phosphodiesterase inhibitors improve performance on the $\mathrm{ED} / \mathrm{ID}$ cognitive task in rats. Neuropharmacology 2012;62:1182-90

[20] Smith SM, Uslaner JM, Cox CD, Huszar SL, Cannon CE, Vardigan JD, et al. The novel phosphodiesterase 10A inhibitor THPP-1 has antipsychotic-like effects in rat and improves cognition in rat and rhesus monkey. Neuropharmacology 2013;64:215-23

[21] Reneerkens OA, Rutten K, Bollen E, Hage T, Blokland A, Steinbusch HW et al. Inhibition of phoshodiesterase type 2 or type 10 reverses object memory deficits induced by scopolamine or MK-801. Behavioural Brain Research 2012;236C:16-22.

[22] Grauer SM, Pulito VL, Navarra RL, Kelly MP, Kelley C, Graf R, et al. Phosphodiesterase $10 \mathrm{~A}$ inhibitor activity in preclinical models of the positive, cognitive, and negative symptoms of schizophrenia. Journal of Pharmacology and Experimental Therapeutics 2009;331:574-90.

[23] Hebb AL, Robertson HA, Denovan-Wright EM. Phosphodiesterase 10A inhibition is associated with locomotor and cognitive deficits and increased anxiety in mice. European Neuropsychopharmacology 2008;18:339-63.

[24] Lakics V, Karran EH, Boess FG. Quantitative comparison of phosphodiesterase mRNA distribution in human brain and peripheral tissues. Neuropharmacology 2010;59:367-74

[25] van Staveren WC, Steinbusch HW, Markerink-van Ittersum M, Behrends $\mathrm{S}$, de Vente J. Species differences in the localization of cGMP-producing and NO-responsive elements in the mouse and rat hippocampus using cGMP immunocytochemistry. The European Journal of Neuroscience 2004; 19 : 2155-68.

[26] Van Staveren WC, Steinbusch HW, Markerink-Van Ittersum M, Repaske DR, Goy MF, Kotera J, et al. mRNA expression patterns of the cGMP-hydrolyzing phosphodiesterases types 2,5, and 9 during development of the rat brain. The Journal of Comparative Neurology 2003;467:566-80.

[27] Stephenson DT, Coskran TM, Kelly MP, Kleiman RJ, Morton D, O’Neill SM, et al. The distribution of phosphodiesterase $2 \mathrm{~A}$ in the rat brain. Neuroscience 2012;226:145-55.

[28] Loughney K, Hill TR, Florio VA, Uher L, Rosman GJ, Wolda SL, et al. Isolation and characterization of cDNAs encoding PDE5A, a human cGMP-binding, cGMP-specific 3',5'-cyclic nucleotide phosphodiesterase. Gene 1998;216: 139-47.

[29] Fujishige K, Kotera J, Michibata H, Yuasa K, Takebayashi S, Okumura K, et al. Cloning and characterization of a novel human phosphodiesterase that hydrolyzes both cAMP and cGMP (PDE10A). The Journal of Biological Chemistry 1999;274:18438-45.

[30] Loughney K, Snyder PB, Uher L, Rosman GJ, Ferguson K, Florio VA. Isolation and characterization of PDE10A, a novel human 3',5'-cyclic nucleotide phosphodiesterase. Gene 1999;234:109-17.

[31] Soderling SH, Bayuga SJ, Beavo JA. Isolation and characterization of a dual-substrate phosphodiesterase gene family: PDE10A. Proceedings of the National Academy of Sciences of the United States of America 1999;96: 7071-6.

[32] Xu Y, Zhang HT, O’Donnell JM. Phosphodiesterases in the central nervous system: implications in mood and cognitive disorders. Handbook of Experimental Pharmacology 2011:447-85.

[33] Schmidt CJ, Chapin DS, Cianfrogna J, Corman ML, Hajos M, Harms JF, et al. Preclinical characterization of selective PDE10A inhibitors: a new therapeutic approach to the treatment of schizophrenia. Journal of Pharmacology and Experimental Therapeutics 2008;325:681-90.

[34] Cromwell HC, Mears RP, Wan L, Boutros NN. Sensory gating: a translational effort from basic to clinical science. Clinincal EEG and Neuroscience 2008;39:69-72.

[35] Halene TB, Siegel SJ. Antipsychotic-like properties of PDE4 inhibitors - evaluation of RO-20-1724 with auditory event related potentials and prepulse inhibition of startle. Journal of Pharmacology and Experimental Therapy 2008;326:230-9.

[36] Adler LE, Pachtman E, Franks RD, Pecevich M, Waldo MC, Freedman R. Neurophysiological evidence for a defect in neuronal mechanisms involved in sensory gating in schizophrenia. Biological Psychiatry 1982;17:639-54.

[37] Javitt DC. Sensory processing in schizophrenia: neither simple nor intact. Schizophrenia Bulletin 2009;35:1059-64.

[38] Jessen F, Kucharski C, Fries T, Papassotiropoulos A, Hoenig K, Maier W, et al Sensory gating deficit expressed by a disturbed suppression of the P50 eventrelated potential in patients with Alzheimer's disease. American Journal of Psychiatry 2001;158:1319-21.

[39] Chang WP, Arfken CL, Sangal MP, Boutros NN. Probing the relative contribution of the first and second responses to sensory gating indices: a meta-analysis. Psychophysiology 2011;48:980-92.

[40] Dalecki A, Croft RJ, Johnstone SJ. An evaluation of P50 paired-click methodologies. Psychophysiology 2011;48:1692-700.

[41] Boutros NN, Brockhaus-Dumke A, Gjini K, Vedeniapin A, Elfakhani M, Burroughs $S$, et al. Sensory-gating deficit of the N100 mid-latency auditory evoked potential in medicated schizophrenia patients. Schizophrenia Research 2009;113:339-46. 
[42] Lijffijt M, Moeller FG, Boutros NN, Burroughs S, Lane SD, Steinberg JL, et al. The role of age, gender, education, and intelligence in P50, N100, and P200 auditory sensory gating. Journal of Psychophysiology 2009;23:52-62.

[43] Broberg BV, Oranje B, Glenthoj BY, Fejgin K, Plath N, Bastlund JF. Assessment of auditory sensory processing in a neurodevelopmental animal model of schizophrenia - gating of auditory-evoked potentials and prepulse inhibition. Behavioural Brain Research 2010;213:142-7.

[44] Mears RP, Boutros NN, Cromwell HC. Reduction of prelimbic inhibitory gating of auditory evoked potentials after fear conditioning. Behavioral Neuroscience 2009;123:315-27.

[45] Mears RP, Klein AC, Cromwell HC. Auditory inhibitory gating in medial prefrontal cortex: single unit and local field potential analysis. Neuroscience 2006;141:47-65.

[46] Zhou D, Ma Y, Liu N, Chen L, He M, Miao Y. Influence of physical parameters of sound on the sensory gating effects of N40 in rats. Neuroscience Letters 2008;432:100-4.

[47] Miyazato H, Skinner RD, Garcia-Rill E. Neurochemical modulation of the P13 midlatency auditory evoked potential in the rat. Neuroscience 1999;92:911-20.

[48] Reneerkens OA, Sambeth A, Van Duinen MA, Blokland A, Steinbusch HW, Prickaerts J. The PDE5 inhibitor vardenafil does not affect auditory sensory gating in rats and humans. Psychopharmacology 2013;225(2):303-12.

[49] Boess FG, De Vry J, Erb C, Flessner T, Hendrix M, Luithle J, et al. The novel alpha7 nicotinic acetylcholine receptor agonist $\mathrm{N}$-[(3R)-1-azabicyclo[2.2.2]oct-3-yl]7-[2-(methoxy)phenyl]-1-benzofuran-2-carboxamide improves working and recognition memory in rodents. Journal of Pharmacology and Experimental Therapeutics 2007;321:716-25.

[50] Bickford-Wimer PC, Nagamoto H, Johnson R, Adler LE, Egan M, Rose GM, et al. Auditory sensory gating in hippocampal neurons: a model system in the rat. Biological Psychiatry 1990;27:183-92.
[51] Cromwell HC, Klein A, Mears RP. Single unit and population responses during inhibitory gating of striatal activity in freely moving rats. Neuroscience 2007;146:69-85.

[52] Paxinos G, Watson C. The rat brain in stereotaxic coordinates. 4th ed. London: Academic Press; 1998.

[53] Singh N, Parle M. Sildenafil improves acquisition and retention of memory in mice. Indian Journal of Physiology and Pharmacology 2003;47: 318-24.

[54] Devan BD, Pistell PJ, Daffin Jr LW, Nelson CM, Duffy KB, Bowker JL, et al. Sildenafil citrate attenuates a complex maze impairment induced by intracerebroventricular infusion of the NOS inhibitor N(omega)-nitro-L-arginine methyl ester. European Journal of Pharmacology 2007;563:134-40.

[55] Devan BD, Sierra-Mercado Jr D, Jimenez M, Bowker JL, Duffy KB, Spangler EL, et al. Phosphodiesterase inhibition by sildenafil citrate attenuates the learning impairment induced by blockade of cholinergic muscarinic receptors in rats. Pharmacology Biochemistry and Behaviour 2004;79:691-9.

[56] Baratti CM, Boccia MM. Effects of sildenafil on long-term retention of an inhibitory avoidance response in mice. Behavioural Pharmacology 1999; 10:731-7.

[57] Siuciak JA. The role of phosphodiesterases in schizophrenia: therapeutic implications. CNS Drugs 2008;22:983-93.

[58] Alderton W, Karran E, Ward S. Current and future perspectives in psychiatric drug discovery. Drug News \& Perspectives 2009;22:360-4.

[59] Bender AT, Beavo JA. Cyclic nucleotide phosphodiesterases: molecular regulation to clinical use. Pharmacological Reviews 2006;58: 488-520.

[60] Maxwell CR, Kanes SJ, Abel T, Siegel SJ. Phosphodiesterase inhibitors: a novel mechanism for receptor-independent antipsychotic medications. Neuroscience 2004;129:101-7. 